\title{
Prenatal and Childhood Adverse Events and Child Brain Morphology:
}

\section{A Population-Based Study}

\section{AUTHORS' NAMES}

Andrea P. Cortes Hidalgo ${ }^{a}$; Scott W. Delaney ${ }^{b}$; Stavroula A. Kourtalidic, Alexander Neumann ${ }^{a}$; Runyu Zou ${ }^{\mathrm{a}}$; Ryan L. Muetzel ${ }^{\mathrm{a}}$; Marian J. Bakermans-Kranenburg ${ }^{\mathrm{d}}$; Marinus H. van IJzendoorn ${ }^{\mathrm{c}}$; Henning Tiemeier, ${ }^{\mathrm{a}, \mathrm{b}}$; Tonya White ${ }^{\mathrm{a}, \mathrm{e}}$

\section{AUTHORS' AFFILIATIONS}

${ }^{\text {a }}$ Department of Child and Adolescent Psychiatry/Psychology, Erasmus MC, Rotterdam

${ }^{\mathrm{b}}$ Department of Social and Behavioral Sciences, Harvard T.H. Chan School of Public Health, Boston

${ }^{c}$ Department of Psychology, Education and Child Studies, Erasmus University Rotterdam, Rotterdam

${ }^{\mathrm{d}}$ Clinical Child \& Family Studies, Vrije Universiteit Amsterdam, Amsterdam

${ }^{\mathrm{e}}$ Department of Radiology and Nuclear Medicine, Erasmus MC, Rotterdam

Running title: Early-Life Adversities and Child Brain Morphology 
medRxiv preprint doi: https://doi.org/10.1101/2021.02.25.21252442; this version posted March 1, 2021. The copyright holder for this preprint (which was not certified by peer review) is the author/funder, who has granted medRxiv a license to display the preprint in perpetuity.

It is made available under a CC-BY-NC-ND 4.0 International license .

\begin{abstract}
Background: Prenatal and childhood adverse events have been shown to be related to children's cognitive and psychological development. However, the influence of early-life adversities on child brain morphology is not well understood and most studies are based on small samples and often examine only one adversity. Thus, the goal of our study is to examine the relationship between cumulative exposures to prenatal and childhood adversities and brain morphology in a large population-based study.
\end{abstract}

Methods: Participants included 2,993 children in whom prenatal adversities were reported by mothers at 20-25 weeks of pregnancy and the child's lifetime exposure to adversities was reported by mothers when the children were 10 years-of-age. The total brain, grey and white matter volumes and the volume of the cerebellum, amygdala and hippocampus were assessed with magnetic resonance imaging when children were 10 years old.

Results: In total, $36 \%$ of children had mothers who were exposed to at least one adversity during pregnancy and $35 \%$ of children were exposed to adversities in childhood. In our study sample, the cumulative number of prenatal adversities was not related to any brain outcome. In contrast, per each additional childhood adverse event, the total brain volume was 0.07 standard deviations smaller $(\mathrm{SE}=0.02, \mathrm{p}=0.001)$, with differences in both grey and white matter volumes. Childhood adversities were not related to the amygdala or hippocampal volumes. Additionally, the link between childhood events and the preadolescent brain was not modified by prenatal events and was not explained by maternal psychopathology.

Conclusions: Our results suggest that childhood adversities, but not prenatal adverse events, are associated with smaller global brain volumes in preadolescence. Notably, this is the first large 
medRxiv preprint doi: https://doi.org/10.1101/2021.02.25.21252442; this version posted March 1, 2021. The copyright holder for this preprint (which was not certified by peer review) is the author/funder, who has granted medRxiv a license to display the preprint in perpetuity. It is made available under a CC-BY-NC-ND 4.0 International license .

EARLY-LIFE ADVERSITIES AND CHILD BRAIN MORPHOLOGY

population-based study to prospectively assess the association between the cumulative number of prenatal adversities and the preadolescent brain morphology. The study findings extend the evidence from high-risk samples, providing support for a link between cumulative childhood adverse events and brain morphology in children from the general population.

Key words: Adversity; childhood; brain; stress; magnetic resonance imaging; pregnancy 
medRxiv preprint doi: https://doi.org/10.1101/2021.02.25.21252442; this version posted March 1, 2021. The copyright holder for this preprint (which was not certified by peer review) is the author/funder, who has granted medRxiv a license to display the preprint in perpetuity.

It is made available under a CC-BY-NC-ND 4.0 International license .

\section{Introduction}

Adversities, defined as the negative experiences that deviate from the expectable environment, need to be chronic (e.g. parental loss), or sufficiently severe to require a considerable psychobiological adaptation (1). Children whose mothers experienced adversities during pregnancy tend to have more behavioral problems (2) and childhood adversities are associated with poorer intellectual performance (3). Although studies in high-risk samples have addressed the relation between early-life adversity and child brain morphology (1), this association is not well documented in the general population.

Few studies have examined the relation between prenatal adversities and offspring neurodevelopment. As reviewed by Franke, Van den Bergh (4), studies examining head circumference (HC) at birth showed mixed results. For example, prenatal adversities were not related to $\mathrm{HC}$ at birth in a population-based sample $(\mathrm{N}=4,211)(5)$, whereas a small positive association was found in a larger cohort $(\mathrm{N}=78,017)(6)$. $\mathrm{HC}$ metrics are easily accessible and a proxy for total brain volume. However, they might not capture region-specific differences (4). Only one study assessed prenatal adversities and child brain morphology using magnetic resonance imaging (MRI) and found that girls whose mothers were exposed to an adverse event in pregnancy had larger amygdala volumes $(\mathrm{N}=68)(2)$. To date, no large population-based study has examined the relation between cumulative prenatal adversities and child brain morphology.

In contrast, there is substantial research on childhood adversities and offspring neurodevelopment, including case-control studies, where adversities are often severe (e.g. institutionalization), and studies in children exposed to a more graded scale of events. Severe adversities have been related to smaller cerebellar (1) and global brain volumes, with differences in multiple brain regions (7). Evidence for differences in the amygdala and hippocampus is 
medRxiv preprint doi: https://doi.org/10.1101/2021.02.25.21252442; this version posted March 1, 2021. The copyright holder for this preprint (which was not certified by peer review) is the author/funder, who has granted medRxiv a license to display the preprint in perpetuity. It is made available under a CC-BY-NC-ND 4.0 International license .

mixed, with both larger $(8,9)$ and smaller volumes (10) reported. Hanson, Nacewicz (10) examined three samples of children exposed to different adversities (physical abuse, neglect, low socioeconomic status (SES)) and found smaller amygdala in relation to all adversities.

Studies in children exposed to more common adversities have reported differences in the cerebellum, cortex and limbic structures. Cumulative childhood adversities were related to smaller cerebellar volumes in a sample of 58 adolescents (11) and to smaller prefrontal cortex, amygdala and hippocampal volumes in a study oversampled for child depression $(12,13)$. Importantly, the adversity definition in the latter study included parental psychopathology. Although having a parent with psychopathology may represent an adversity, shared genetic factors may underlie the association (4) and parental psychopathology may additionally interact with the adversities' effect (14).

Previous studies $(7,10)$ described similar findings in relation to different adversities, which could imply a low specificity across adversity types. Evidence also suggests a cumulative relation between childhood adversities and numerous outcomes, including health-risk behaviors and psychiatric disorders (15). Thus, we assessed the cumulative effect of early-life adversities on brain morphology. Compared to examining single adversities, the cumulative adversity assessment (15) offers a more naturalistic view of the adversity exposure, because adverse events are often related and tend to co-occur (16).

Notably, a randomized-controlled trial in institutionalized children demonstrated that cognitive outcomes improved when children were placed into foster care, especially if this placement occurred at younger ages (3). Bick and Nelson (7) additionally described smaller gray matter volumes in children ever-institutionalized compared to those never-institutionalized. 
medRxiv preprint doi: https://doi.org/10.1101/2021.02.25.21252442; this version posted March 1, 2021. The copyright holder for this preprint (which was not certified by peer review) is the author/funder, who has granted medRxiv a license to display the preprint in perpetuity.

It is made available under a CC-BY-NC-ND 4.0 International license .

Thus, child neurodevelopment can improve, within the available biological reserve, after adversity ceases (17). This has two implications for our study. First, the timing of adversity exposure may influence the association with brain morphology. Children with no childhood adversities, but whose mothers experienced adversities during pregnancy may show differences due to the pronounced neurodevelopment that occurs during prenatal life (17). Children with adversities in both the prenatal and childhood periods may have the largest brain differences. Thus, we examined adversities in both periods in relation to child brain morphology. Second, when adversity occurs only prenatally, the brain development could "catch-up", approaching the typical growth curve (17). To examine this neuroplasticity, we included fetal HC measures in sensitivity analyses.

In this population-based study, we examined the relationship between cumulative prenatal and childhood adversities and the preadolescent brain morphology. We hypothesized a greater number of adversities would be related to smaller global brain, amygdala and hippocampal volumes. We additionally hypothesized a stronger association between childhood adversities and brain morphology in children whose mothers were exposed to prenatal adversities.

\section{Materials and Methods}

\section{Participants}

This study is part of the Generation R Study, a population-based prenatal birth cohort in Rotterdam, the Netherlands (18). In total, 9,778 pregnant mothers with a delivery date from April 2002 to January 2006 were enrolled, and information was collected from children and parents by questionnaires, interviews and research visits. Study protocols for each wave of data collection were approved by the Medical Ethical Committee of the Erasmus Medical Center and all parents gave written informed consent. 
medRxiv preprint doi: https://doi.org/10.1101/2021.02.25.21252442; this version posted March 1, 2021. The copyright holder for this preprint (which was not certified by peer review) is the author/funder, who has granted medRxiv a license to display the preprint in perpetuity. It is made available under a CC-BY-NC-ND 4.0 International license .

$\mathrm{T}_{1}$-weighted MRI scans were acquired in 3,966 9-to-11-year-old children (19), of which 3,186 had good image quality data. Among these children, 3,146 had complete information on prenatal and/or childhood adversities. We randomly excluded one sibling ( $\mathrm{N}=153)$ to avoid nonindependent data. In total, 2,993 children were included in analyses (2,242 in prenatal adversities analyses and 2,923 in childhood adversities analyses; Figure S1).

\section{Measures}

\section{Prenatal adversities}

Adverse events occurring prenatally and shortly before pregnancy were assessed with a Dutchadapted version of the Social Readjustment Rating Scale (SRRS)(20). At 20-25 weeks of pregnancy, mothers reported the occurrence of ten stressful events in the preceding 12 months (e.g. serious illnesses of family members, partner's death)(21). An additional question on the occurrence of robbery, theft, physical abuse or rape was also included, given the relevance of these adverse experiences. Moving to a new home, originally assessed by the SRRS, was excluded as it could also reflect a positive situation. A 'prenatal adversities score' was computed as the cumulative number of occurrences of ten adverse events (Table S1).

\section{Childhood adversities}

Occurrence of stressful life events from birth to age 10 years was reported by mothers during an interview when children were 10 years old (22). This instrument was based on the TRAILS study questionnaires (23) and the Life Events and Difficulty Schedule (24), and comprised twenty-four events of varying severity (e.g. high school workload, parental conflicts). To better measure severe adversities in this population-based sample, specific adverse events were selected using as reference the ACEs studies (e.g. Felitti, Anda (15)). A 'childhood adversities score' was computed as the cumulative occurrence of these adversities (Table S2). 
medRxiv preprint doi: https://doi.org/10.1101/2021.02.25.21252442; this version posted March 1, 2021. The copyright holder for this preprint (which was not certified by peer review) is the author/funder, who has granted medRxiv a license to display the preprint in perpetuity. It is made available under a CC-BY-NC-ND 4.0 International license .

EARLY-LIFE ADVERSITIES AND CHILD BRAIN MORPHOLOGY

\section{Brain Imaging}

Brain MRI data were obtained in 9-11-year-old children using a 3 Tesla GE 750w Discovery platform (General Electric, Milwaukee, WI)(19). T$_{1}$-weighted images were collected with a receive-only 8-channel head coil and an inversion recovery fast spoil gradient recalled sequence $\left(\mathrm{TR}=8.77 \mathrm{~ms}, \mathrm{TE}=3.4 \mathrm{~ms}, \mathrm{TI}=600 \mathrm{~ms}\right.$, Flip angle $=10^{\circ}$, Field of view $=220 \times 220$, Acquisition matrix $=220 x 220$, Slice thickness $=1 \mathrm{~mm}$, Number of slices=230, ARC acceleration factor=2).

We processed and conducted the segmentation and reconstruction of the neuroimaging data with the FreeSurfer image analysis suite (v.6.0)(25). Reconstructed images were inspected for quality and poor quality reconstructions were excluded from further analyses (26). The total brain volume, the cortical grey and cerebral white matter volumes, the cerebellar volume, and the amygdala and hippocampal volumes were included in analyses.

\section{Ultrasound measures}

Fetal ultrasound measures were collected at three time-points during pregnancy (27). Trained sonographers established the gestational age based on the first ultrasound assessment and measured fetal $\mathrm{HC}$ using standardized techniques (28). The HC measures collected during the third trimester of pregnancy were included in sensitivity analyses.

\section{Covariates}

We included as covariates child sex and age at the MRI scan, total intracranial volume, maternal ethnicity, highest household education and maternal prenatal alcohol use and smoking. Child sex was collected from birth records. Maternal ethnicity was defined based on her parents' birth country and was self-reported during pregnancy. The highest household education, and prenatal alcohol consumption and smoking were reported through questionnaires during pregnancy (See Supplemental Information). 
medRxiv preprint doi: https://doi.org/10.1101/2021.02.25.21252442; this version posted March 1, 2021. The copyright holder for this preprint (which was not certified by peer review) is the author/funder, who has granted medRxiv a license to display the preprint in perpetuity. It is made available under a CC-BY-NC-ND 4.0 International license .

Maternal psychopathology in pregnancy was assessed with the Brief Symptom Inventory, a validated and widely-used questionnaire (29). We used the global severity index score, a measure of the global severity of psychopathology, in additional analyses.

\section{Statistical Analyses}

We examined the associations of prenatal and childhood adversities with the brain outcomes using multiple linear regression. We first fitted a minimally adjusted model controlling for child sex and age at MRI scan, total intracranial volume (in amygdala and hippocampus analyses) and maternal ethnicity. To account for confounding by SES, we additionally adjusted for the highest household education in a second model. Finally, we also controlled for prenatal alcohol use and smoking in a third, fully-adjusted model, since these factors could be also considered part of the pathway between prenatal adversities and brain morphology.

We subsequently examined the interaction between prenatal and childhood adversities in relation to brain morphology. Additionally, for descriptive purposes, we assessed the relation between a categorical adversity measure and the brain outcomes, using four groups: children with one or more prenatal adversities only $(\mathrm{N}=460)$, children with one or more childhood adversities only $(\mathrm{N}=433)$, children with adversities in both periods $(\mathrm{N}=321)$, and children with no adversities $(\mathrm{N}=958)$.

Several sensitivity analyses were performed. We first examined whether child sex modified the associations between adversity and brain morphology. Second, we analyzed the associations of adversity and brain morphology in a more homogeneous group, children whose mothers had a Dutch national origin. Third, we explored whether associations between adversity and brain morphology were explained by maternal psychopathology, and we examined the interaction between maternal psychopathology and adversity in relation to child brain 
medRxiv preprint doi: https://doi.org/10.1101/2021.02.25.21252442; this version posted March 1, 2021. The copyright holder for this preprint (which was not certified by peer review) is the author/funder, who has granted medRxiv a license to display the preprint in perpetuity. It is made available under a CC-BY-NC-ND 4.0 International license .

morphology. Finally, to explore the role of brain plasticity (17), we assessed whether prenatal adversities were associated with $\mathrm{HC}$ at the last pregnancy trimester, as $\mathrm{HC}$ is a proxy for an early measure of total brain volume (analyses adjusted for gestational age at ultrasound).

Analyses were performed in R v.3.6.1 (30). Outcomes were standardized. Multiple imputation of missing values (maximum missingness: maternal psychopathology $=23.4 \%$ ) was performed ("mice" package (31)), and results were pooled across 25 imputed datasets. We found no signs of violation of the regression assumptions (i.e. independence, normal distribution, homoscedasticity). Adjustment for multiple testing was performed using the FDR approach (32) in the analyses with prenatal adversities, childhood adversities and the interaction between prenatal and childhood adversities (15 tests, including all brain outcomes, except for total brain volume).

\section{Non-response analyses}

Children included in the analyses of prenatal adversities and brain morphology $(\mathrm{N}=2,242)$ were compared to children with data on prenatal adversities but no neuroimaging data available $(\mathrm{N}=3,552)$. Continuous variables were compared with the Mann-Whitney U test and categorical variables with chi-squared tests. Mothers of children without imaging data were more often exposed to prenatal adversities (one or more events: 40.7\%) than those of children in analyses (one or more events: $36.1 \%$ ) and were less often highly educated $(22.1 \%$ vs $30.5 \%)$.

Additionally, mothers of children without imaging data were less often from Dutch origins (No imaging data group: 50.6\%; Study sample: $61.1 \%$ ) and had more psychiatric symptoms (median $(\mathrm{IQR})=0.19(0.1,0.4))$ than those in analyses $($ median $(\mathrm{IQR})=0.15(0.1,0.3))$.

\section{Results}


medRxiv preprint doi: https://doi.org/10.1101/2021.02.25.21252442; this version posted March 1, 2021. The copyright holder for this preprint (which was not certified by peer review) is the author/funder, who has granted medRxiv a license to display the preprint in perpetuity. It is made available under a CC-BY-NC-ND 4.0 International license .

In total, $36 \%$ of children had mothers who were exposed to at least one prenatal adversity and $35 \%$ of children were exposed to adversities during childhood (Table 1). The most commonly reported prenatal event was a substantial financial downturn (14.5\%), followed by a serious illness of a family member (11.6\%)(Table S1). In childhood, parental separation or divorce was the most prevalent event $(21.45 \%)$ (Table S2). Children with mothers exposed to prenatal adversities were more likely to experience adversities during childhood (41\%) compared to those without prenatal adversities (31\%).

The cumulative number of prenatal adverse events was not related to any brain outcome (Table 2). In contrast, a consistent association was found between childhood adversities and all global brain metrics (total brain, cortical grey and white matter volumes and total cerebellar volumes). Children had, on average, a 0.11 standard-deviation smaller total brain volume $(\mathrm{SE}=0.02, \mathrm{p}<0.001)$ per each additional childhood adverse event, adjusting for child sex, age at the MRI scan, and maternal ethnicity. The associations between childhood adversities and the total brain, cortical grey and white matter volumes remained after adjustment for parental education, and prenatal alcohol use and smoking (Total brain volume: $\mathrm{B}=-0.07, \mathrm{SE}=0.02$, $\mathrm{p}=0.001$ ). Childhood adversities were not related to the amygdala and hippocampus (Table 2). After adjustment for multiple testing, the associations between childhood adversities and the cortical grey (p-adjusted=0.02), and cerebral white matter volumes ( $\mathrm{p}$-adjusted=0.02) remained.

No interaction was observed between prenatal and childhood adversities in relation to child brain morphology (Table 3 ). Also, when using the categorical adversity measure, the exposure to only prenatal adversities was not related to the total brain volume, whereas the specific exposure to childhood adversities was associated with a 0.10 standard-deviation smaller total brain volume $(\mathrm{p}=0.04)$. Additionally, children with adversities in both periods had a 0.10 
medRxiv preprint doi: https://doi.org/10.1101/2021.02.25.21252442; this version posted March 1, 2021. The copyright holder for this preprint (which was not certified by peer review) is the author/funder, who has granted medRxiv a license to display the preprint in perpetuity. It is made available under a CC-BY-NC-ND 4.0 International license .

standard-deviation smaller total brain volume than those non-exposed $(\mathrm{p}=0.06)$. Altogether, our results suggest that only childhood events are related to brain morphology and that this association is independent of the occurrence of prenatal adversities (Figure 1).

We further examined the specificity of the association between childhood adversities and brain morphology. No interaction was found between child sex and childhood adversities for any brain outcome. When including only children with Dutch mothers, childhood adversities were related to the total brain, grey and white matter, and cerebellar volumes (Table S3). Also, the associations between childhood adversities and brain morphology were not explained nor modified by maternal prenatal psychopathology (Table S4). Finally, the cumulative number of prenatal adversities was not related to variations in the fetal $\mathrm{HC}(\mathrm{B}=0.00, \mathrm{SE}=0.02, \mathrm{p}=0.82$; $\mathrm{N}=2,168)$.

\section{Discussion}

In this population-based study, childhood adversities, but not prenatal adverse events experienced by the mother, were related to global brain volume differences at age 10 years. Our study provides two novel contributions to the literature. This is the first study to examine the association between cumulative prenatal adversities and brain structure in children from the general population. Contrary to our hypothesis, we found no relationship between cumulative prenatal adversities and preadolescent brain morphology using a large population-based sample, an assessment of prenatal adversities while mothers were pregnant and neuroimaging data. Second, cumulative childhood adversities were related to smaller total brain volumes and differences were observed across grey and white matter volumes. These findings are consistent with research in some small high-risk samples, supporting a relation between cumulative childhood adversities and child neurodevelopment. 
medRxiv preprint doi: https://doi.org/10.1101/2021.02.25.21252442; this version posted March 1, 2021. The copyright holder for this preprint (which was not certified by peer review) is the author/funder, who has granted medRxiv a license to display the preprint in perpetuity. It is made available under a CC-BY-NC-ND 4.0 International license .

The absence of associations between prenatal adversities and child brain morphology is surprising, as the brain undergoes dramatic developmental changes during pregnancy (17). Our study may have lacked sufficient power to observe subtle effects. However, we assessed a considerably larger sample than previous studies (2). The brain can adapt in response to environmental effects (7), which raises the question of whether brain plasticity could have obscured an association between prenatal adversities and brain morphology. Given a rich and positive childhood environment, the brain development of children whose mothers experienced stress in pregnancy could catch-up and return to the normative trajectory (17). If this were the case, prenatal adversities would be related to brain differences earlier in life. However, we found no association between prenatal events and $\mathrm{HC}$ in the last pregnancy trimester, arguing against the plasticity hypothesis (17) (see also a study from this cohort examining family dysfunction and fetal $\mathrm{HC}(27))$. It is also possible that the adversity type and severity influence the relation with brain morphology. Whereas Jones, Dufoix (2) found a relation between the gestational exposure to a natural disaster and amygdala volumes, the cumulative exposure to a range of more normative adverse events was not associated with the global brain volume nor the amygdala and hippocampus in our study.

Numerous studies have examined childhood adversity and brain morphology, but results are difficult to compare due to differences in the events assessed, the age of occurrence of adversities and the age at the MRI assessment (7). Overall, research suggests that children exposed to early-life adversity have smaller total brain, grey and white matter, and cerebellar volumes (7). Consistently, we observed that childhood adversity was related to smaller total brain volumes, and this finding was robust to the adjustment for confounders. Analyses with the grey and white matter volumes further supported this association. Additionally, maternal 
medRxiv preprint doi: https://doi.org/10.1101/2021.02.25.21252442; this version posted March 1, 2021. The copyright holder for this preprint (which was not certified by peer review) is the author/funder, who has granted medRxiv a license to display the preprint in perpetuity. It is made available under a CC-BY-NC-ND 4.0 International license .

psychopathology did not explain nor modify the relation between childhood adversity and these brain outcomes.

Contrary to what we expected, childhood adversities were not related to the limbic volumes. The amygdala and hippocampus are of particular interest because they have a high density of cortisol receptors and cortisol influences the neuronal development (4). Interestingly, both larger and smaller amygdala and hippocampal volumes have been reported (8-10). In addition to the methodological differences across studies, various hypotheses could underlie these mixed findings. The volumetric growth of the amygdala and hippocampus peaks at around age 10 years (33), thus different findings could be expected between studies assessing brain morphology during childhood, preadolescence, and at later ages. The adversity severity may also influence the results, and the impact of early adversity in some structures may only become apparent later in development (7). Further, the amygdala (34) and hippocampus (35) show continued neurogenesis after fetal life, suggesting that these regions could undergo plastic changes in response to adversity and other environmental factors.

Our adversity measures were selected with a focus on concrete environmental events, that could generate stress in the pregnant mother or the child and require a substantial psychobiological adaptation (1). The cumulative prenatal adversity measure was based on a major life events inventory (20), similar to those included in other population-based studies (36). Similarly, our childhood adversity measure included events assessed by key childhood adversities studies $(15,37)$, previously shown to be associated with greater child psychopathology (22). Different items were used in the prenatal and childhood adversity measures, to focus on maternal stressful events in the prenatal measure, and on childhood 
medRxiv preprint doi: https://doi.org/10.1101/2021.02.25.21252442; this version posted March 1, 2021. The copyright holder for this preprint (which was not certified by peer review) is the author/funder, who has granted medRxiv a license to display the preprint in perpetuity.

It is made available under a CC-BY-NC-ND 4.0 International license .

adverse events in the latter measure. Consistent with previous studies (36), the cumulative exposure to prenatal adversities was related to the number of childhood adversities.

Our study has some limitations. First, we did not account for the age of occurrence of childhood adversities. Although events at specific ages could have different effects in brain morphology, it is difficult to determine the exact period of occurrence of adversities that are often chronic and variable (2). Second, mothers reported childhood adversities at age 10 years and thus these reports could be affected by recall bias. Nonetheless, other methods to collect information on childhood adversity in the general population, such as adolescent reports, are limited by the accuracy in reporting early-life events (8). Third, mothers of children without imaging data were more often exposed to prenatal adversities and were less often highly educated than mothers in our study. Finally, by including events that occurred before pregnancy, we could have miss-classified some women who were not experiencing prenatal stress as exposed. However, cumulative preconception adversities have also been shown to predict poor offspring outcomes (38).

\section{Conclusion}

In conclusion, we found that the number of adversities experienced by the mother during pregnancy was not related to brain morphological differences in children from the general population. Childhood adversities consistently predicted smaller brain volumes, with alterations in both grey and white matter volumes. The association between childhood adversities and the global brain volume was not modified by maternal psychopathology, nor by the number of prenatal adversities. Our results support a cumulative association between childhood adversities and brain morphology, previously described in small high-risk samples. If replicated in large 
medRxiv preprint doi: https://doi.org/10.1101/2021.02.25.21252442; this version posted March 1, 2021. The copyright holder for this preprint (which was not certified by peer review) is the author/funder, who has granted medRxiv a license to display the preprint in perpetuity. It is made available under a CC-BY-NC-ND 4.0 International license.

EARLY-LIFE ADVERSITIES AND CHILD BRAIN MORPHOLOGY

samples with repeated MRI and adversity assessments, priority should be given to intervention studies that determine whether providing additional support to children following periods of adversities will prevent the emergence of brain differences. 
medRxiv preprint doi: https://doi.org/10.1101/2021.02.25.21252442; this version posted March 1, 2021. The copyright holder for this preprint (which was not certified by peer review) is the author/funder, who has granted medRxiv a license to display the preprint in perpetuity.

It is made available under a CC-BY-NC-ND 4.0 International license .

EARLY-LIFE ADVERSITIES AND CHILD BRAIN MORPHOLOGY

\section{Ethics Statement}

All study protocols and the measurements assessed in each wave of data collection were approved by the Medical Ethical Committee of the Erasmus MC, University Medical Center Rotterdam.

\section{Data Availability}

The datasets analyzed in this study are currently not publicly available due to legal and ethical restraints due to the General Data Protection Regulations (GDPR). However the consent has been altered for the current wave of data collection which will provide the participants the option to determine the extent that they want their data shared. Via data transfer agreements, the data can be made available upon request. Interested researchers can direct their requests to Vincent Jaddoe (v.jaddoe@erasmusmc.nl).

\section{Acknowledgements}

This work was supported by the Netherlands Organization for Health Research and Development (ZonMw TOP 91211021), Spinoza prize, the National Institutes of Health (F31HD096820), the Harry Frank Guggenheim Foundation, the Dutch Ministry of Education, Culture, and Science (NWO 024.001.003 and 016.VICI.170.200), the Canadian Institutes of Health Research, the European Research Council (ERC-AdG.669249), the China Scholarship Council (201606100056), the Sophia Foundation (S18-20), NWO Physical Sciences Division and

SURFsara. The Generation R Study is supported by Erasmus MC, the Erasmus University Rotterdam, ZonMw, NWO, and the Ministry of Health, Welfare and Sport. 
medRxiv preprint doi: https://doi.org/10.1101/2021.02.25.21252442; this version posted March 1, 2021. The copyright holder for this preprint (which was not certified by peer review) is the author/funder, who has granted medRxiv a license to display the preprint in perpetuity.

It is made available under a CC-BY-NC-ND 4.0 International license .

EARLY-LIFE ADVERSITIES AND CHILD BRAIN MORPHOLOGY

CORRESPONDENCE TO: Tonya White, MD, PhD, Child and Adolescent Psychiatry

Department, Erasmus MC, Dr. Molewaterplein 60, Kp-2869, 3000 CB Rotterdam, the

Netherlands. Email:t.white@erasmusmc.nl 
medRxiv preprint doi: https://doi.org/10.1101/2021.02.25.21252442; this version posted March 1, 2021. The copyright holder for this preprint (which was not certified by peer review) is the author/funder, who has granted medRxiv a license to display the preprint in perpetuity.

It is made available under a CC-BY-NC-ND 4.0 International license .

EARLY-LIFE ADVERSITIES AND CHILD BRAIN MORPHOLOGY

\section{References}

1. McLaughlin KA, Weissman D, Bitrán D. Childhood Adversity and Neural Development: A Systematic Review. Annual Review of Developmental Psychology. 2019;1(1):277-312.

2. Jones SL, Dufoix R, Laplante DP, Elgbeili G, Patel R, Chakravarty MM, et al. Larger Amygdala Volume Mediates the Association Between Prenatal Maternal Stress and Higher Levels of Externalizing Behaviors: Sex Specific Effects in Project Ice Storm. Frontiers in Human Neuroscience. 2019;13(144).

3. Nelson III CA, Zeanah CH, Fox NA, Marshall PJ, Smyke AT, Guthrie D. Cognitive Recovery in Socially Deprived Young Children: The Bucharest Early Intervention Project. Science. 2007;318(5858):1937-40.

4. Franke K, Van den Bergh BRH, de Rooij SR, Kroegel N, Nathanielsz PW, Rakers F, et al. Effects of maternal stress and nutrient restriction during gestation on offspring neuroanatomy in humans. Neuroscience \& Biobehavioral Reviews. 2020.

5. Obel C, Hedegaard M, Henriksen TB, Secher NJ, Olsen J. Stressful life events in pregnancy and head circumference at birth. Developmental Medicine \& Child Neurology. 2003;45(12):802-6.

6. Tegethoff M, Greene N, Olsen J, Meyer AH, Meinlschmidt G. Maternal Psychosocial Adversity During Pregnancy Is Associated With Length of Gestation and Offspring Size at Birth: Evidence From a Population-Based Cohort Study. Psychosomatic Medicine. 2010;72(4):419-26.

7. Bick J, Nelson CA. Early Adverse Experiences and the Developing Brain. Neuropsychopharmacology. 2016;41(1):177-96.

8. Roth MC, Humphreys KL, King LS, Gotlib IH. Self-reported neglect, amygdala volume, and symptoms of anxiety in adolescent boys. Child Abuse \& Neglect. 2018;80:80-9.

9. Tupler LA, De Bellis MD. Segmented Hippocampal Volume in Children and Adolescents with Posttraumatic Stress Disorder. Biological Psychiatry. 2006;59(6):523-9. 
medRxiv preprint doi: https://doi.org/10.1101/2021.02.25.21252442; this version posted March 1, 2021. The copyright holder for this preprint (which was not certified by peer review) is the author/funder, who has granted medRxiv a license to display the preprint in perpetuity.

It is made available under a CC-BY-NC-ND 4.0 International license .

EARLY-LIFE ADVERSITIES AND CHILD BRAIN MORPHOLOGY

10. Hanson JL, Nacewicz BM, Sutterer MJ, Cayo AA, Schaefer SM, Rudolph KD, et al. Behavioral

Problems After Early Life Stress: Contributions of the Hippocampus and Amygdala. Biological Psychiatry. $2015 ; 77(4): 314-23$.

11. Walsh ND, Dalgleish T, Lombardo MV, Dunn VJ, Van Harmelen A-L, Ban M, et al. General and specific effects of early-life psychosocial adversities on adolescent grey matter volume. Neurolmage: Clinical. 2014;4:308-18.

12. Luby JL, Barch D, Whalen D, Tillman R, Belden A. Association Between Early Life Adversity and Risk for Poor Emotional and Physical Health in Adolescence: A Putative Mechanistic Neurodevelopmental Pathway. JAMA Pediatrics. 2017;171(12):1168-75.

13. Luby JL, Tillman R, Barch DM. Association of Timing of Adverse Childhood Experiences and Caregiver Support With Regionally Specific Brain Development in Adolescents. JAMA Network Open. 2019;2(9):e1911426-e.

14. Bergink V, Larsen JT, Hillegers MHJ, Dahl SK, Stevens H, Mortensen PB, et al. Childhood adverse life events and parental psychopathology as risk factors for bipolar disorder. Translational Psychiatry. 2016;6(10):e929-e.

15. Felitti VJ, Anda RF, Nordenberg D, Williamson DF, Spitz AM, Edwards V, et al. Relationship of childhood abuse and household dysfunction to many of the leading causes of death in adults: The Adverse Childhood Experiences (ACE) Study. American journal of preventive medicine. 1998;14(4):24558.

16. Smith KE, Pollak SD. Rethinking Concepts and Categories for Understanding the Neurodevelopmental Effects of Childhood Adversity. Perspectives on Psychological Science. 2020;0(0).

17. White TJH. Brain Development and Stochastic Processes During Prenatal and Early Life: You Can't Lose It if You've Never Had It; But It's Better to Have It and Lose It, Than Never to Have Had It at All. Journal of the American Academy of Child \& Adolescent Psychiatry. 2019;58(11):1042-50. 
medRxiv preprint doi: https://doi.org/10.1101/2021.02.25.21252442; this version posted March 1, 2021. The copyright holder for this preprint (which was not certified by peer review) is the author/funder, who has granted medRxiv a license to display the preprint in perpetuity.

It is made available under a CC-BY-NC-ND 4.0 International license .

EARLY-LIFE ADVERSITIES AND CHILD BRAIN MORPHOLOGY

18. Jaddoe VWV, van Duijn CM, Franco OH, van der Heijden AJ, van IJzendoorn MH, de Jongste JC, et al. The Generation R Study: design and cohort update 2012. Eur J Epidemiol. 2012;27(9):739-56.

19. White TJH, Muetzel RL, El Marroun H, Blanken LME, Jansen P, Bolhuis K, et al. Paediatric population neuroimaging and the Generation R Study: the second wave. Eur J Epidemiol. 2018;33(1):99125.

20. Miller MA, Rahe RH. Life changes scaling for the 1990s. Journal of Psychosomatic Research. 1997;43(3):279-92.

21. Molenaar NM, Tiemeier H, van Rossum EFC, Hillegers MHJ, Bockting CLH, Hoogendijk WJG, et al. Prenatal maternal psychopathology and stress and offspring HPA axis function at 6 years. Psychoneuroendocrinology. 2019;99:120-7.

22. Dunn EC, Nishimi K, Neumann A, Renaud A, Cecil CAM, Susser ES, et al. Time-dependent effects of exposure to physical and sexual violence on psychopathology symptoms in late childhood: In search of sensitive periods in development J Am Acad Child Psy. 2019.

23. Amone-P'Olak K, Ormel J, Huisman M, Verhulst FC, Oldehinkel AJ, Burger H. Life Stressors as Mediators of the Relation Between Socioeconomic Position and Mental Health Problems in Early Adolescence: The TRAILS Study. Journal of the American Academy of Child \& Adolescent Psychiatry. 2009;48(10):1031-8.

24. Brown GW, Harris T. Social Origins of Depression: A study of psychiatric disorder in women. London: Tavistock; 1978.

25. Fischl B. FreeSurfer. Neurolmage. 2012;62(2):774-81.

26. Muetzel RL, Blanken LME, Ende Jvd, Marroun HE, Shaw P, Sudre G, et al. Tracking Brain Development and Dimensional Psychiatric Symptoms in Children: A Longitudinal Population-Based Neuroimaging Study. American Journal of Psychiatry. 2018;175(1):54-62. 
medRxiv preprint doi: https://doi.org/10.1101/2021.02.25.21252442; this version posted March 1, 2021. The copyright holder for this preprint (which was not certified by peer review) is the author/funder, who has granted medRxiv a license to display the preprint in perpetuity.

It is made available under a CC-BY-NC-ND 4.0 International license .

EARLY-LIFE ADVERSITIES AND CHILD BRAIN MORPHOLOGY

27. Henrichs J, Schenk JJ, Roza SJ, van den Berg MP, Schmidt HG, Steegers EAP, et al. Maternal psychological distress and fetal growth trajectories: The Generation R Study. Psychological Medicine. 2010;40(4):633-43.

28. Verburg BO, Steegers EAP, De Ridder M, Snijders RJM, Smith E, Hofman A, et al. New charts for ultrasound dating of pregnancy and assessment of fetal growth: longitudinal data from a populationbased cohort study. Ultrasound in Obstetrics \& Gynecology. 2008;31(4):388-96.

29. Derogatis LR. Brief Symptom Inventory (BSI): Administration, Scoring and Procedures Manual. 3rd ed: Minneapolis, MN: National Computer Systems; 1993.

30. R Core Team. R:A language and Environment for Statistical Computing. Vienna, Austria: R Foundation for Statistical Computing; 2018.

31. van Buuren S, Groothuis-Oudshoorn K. mice: Multivariate Imputation by Chained Equations in R. Journal of Statistical Software. 2011;45(3):67.

32. Benjamini Y, Hochberg Y. Controlling the False Discovery Rate - a Practical and Powerful Approach to Multiple Testing. J Roy Stat Soc B Met. 1995;57(1):289-300.

33. Uematsu A, Matsui M, Tanaka C, Takahashi T, Noguchi K, Suzuki M, et al. Developmental Trajectories of Amygdala and Hippocampus from Infancy to Early Adulthood in Healthy Individuals. PLOS ONE. 2012;7(10):e46970.

34. Jhaveri DJ, Tedoldi A, Hunt S, Sullivan R, Watts NR, Power JM, et al. Evidence for newly generated interneurons in the basolateral amygdala of adult mice. Mol Psychiatr. 2018;23(3):521-32.

35. Imayoshi I, Sakamoto M, Ohtsuka T, Takao K, Miyakawa T, Yamaguchi M, et al. Roles of continuous neurogenesis in the structural and functional integrity of the adult forebrain. Nature Neuroscience. 2008;11(10):1153-61. 
medRxiv preprint doi: https://doi.org/10.1101/2021.02.25.21252442; this version posted March 1, 2021. The copyright holder for this preprint (which was not certified by peer review) is the author/funder, who has granted medRxiv a license to display the preprint in perpetuity. It is made available under a CC-BY-NC-ND 4.0 International license.

EARLY-LIFE ADVERSITIES AND CHILD BRAIN MORPHOLOGY

36. Jensen SKG, Pangelinan M, Björnholm L, Klasnja A, Leemans A, Drakesmith M, et al. Associations between prenatal, childhood, and adolescent stress and variations in white-matter properties in young men. Neurolmage. 2018;182:389-97.

37. Dong M, Anda RF, Felitti VJ, Dube SR, Williamson DF, Thompson TJ, et al. The interrelatedness of multiple forms of childhood abuse, neglect, and household dysfunction. Child abuse \& neglect. 2004;28(7):771-84.

38. Witt WP, Cheng ER, Wisk LE, Litzelman K, Chatterjee D, Mandell K, et al. Maternal Stressful Life Events Prior to Conception and the Impact on Infant Birth Weight in the United States. American Journal of Public Health. 2014;104(S1):S81-S9. 
medRxiv preprint doi: https://doi.org/10.1101/2021.02.25.21252442; this version posted March 1, 2021. The copyright holder for this preprint (which was not certified by peer review) is the author/funder, who has granted medRxiv a license to display the preprint in perpetuity. It is made available under a CC-BY-NC-ND 4.0 International license.

EARLY-LIFE ADVERSITIES AND CHILD BRAIN MORPHOLOGY

\section{Tables and Figures}

Table 1. Baseline characteristics

\begin{tabular}{|c|c|c|}
\hline & $\begin{array}{c}\text { mean (SD) or } \\
\% *\end{array}$ & $\mathbf{N}$ \\
\hline \multicolumn{3}{|l|}{ Adversity measures } \\
\hline \multicolumn{3}{|l|}{ Prenatal adversities (10 items), \% (N=2242) } \\
\hline 0 & 63.9 & 1432 \\
\hline 1 & 20.6 & 461 \\
\hline 2 & 10.5 & 236 \\
\hline 3 & 3.8 & 85 \\
\hline 4 or more & 1.2 & 28 \\
\hline \multicolumn{3}{|l|}{ Childhood adversities (4 items), \% (N=2923) } \\
\hline 0 & 64.9 & 1897 \\
\hline 1 & 27.2 & 795 \\
\hline 2 & 6.3 & 185 \\
\hline 3 & 1.4 & 41 \\
\hline 4 & 0.2 & 5 \\
\hline \multicolumn{3}{|l|}{ Child characteristics } \\
\hline Sex, \% girls & 50.8 & 1521 \\
\hline Age at MRI scan, years & $10.1(0.6)$ & 2993 \\
\hline \multicolumn{3}{|l|}{ Parental Characteristics } \\
\hline Maternal ethnicity, \% & & 2993 \\
\hline Dutch & 57.6 & 1725 \\
\hline Non-Western & 30.3 & 906 \\
\hline Other Western & 12.1 & 362 \\
\hline Highest household education, \% & & 2993 \\
\hline Low education & 41.0 & 1227 \\
\hline Medium education & 22.4 & 670 \\
\hline High education & 36.6 & 1096 \\
\hline Maternal prenatal alcohol use, $\%$ never during pregnancy & 41.0 & 1226 \\
\hline Maternal prenatal smoking, \% never during pregnancy & 76.9 & 2303 \\
\hline Maternal Psychiatric Symptoms, median (Q1,Q3) & $0.15(0.06,0.32)$ & 2993 \\
\hline
\end{tabular}

Characteristics of the sample with information for prenatal AND/OR childhood adversities and brain structural MRI data (N=2993). *Otherwise indicated. Based on imputed datasets. 
Table 2. Associations between cumulative prenatal and childhood adversities and child brain morphology

\begin{tabular}{|c|c|c|c|c|c|c|c|c|c|}
\hline & \multicolumn{3}{|c|}{ Model 1} & \multicolumn{3}{|c|}{ Model 2} & \multicolumn{3}{|c|}{ Model 3} \\
\hline & B & SE & $\mathbf{P}$ & B & SE & $\mathbf{P}$ & B & SE & $\mathbf{P}$ \\
\hline \multicolumn{10}{|l|}{ Prenatal adversities } \\
\hline \multicolumn{10}{|l|}{ Global brain metrics } \\
\hline Total brain volume & -0.03 & 0.02 & 0.14 & -0.02 & 0.02 & 0.39 & -0.01 & 0.02 & 0.52 \\
\hline Cortical grey matter volume & -0.03 & 0.02 & 0.20 & -0.01 & 0.02 & 0.57 & -0.01 & 0.02 & 0.71 \\
\hline Cerebral white matter volume & -0.02 & 0.02 & 0.23 & -0.02 & 0.02 & 0.41 & -0.01 & 0.02 & 0.56 \\
\hline Total cerebellar volume & -0.03 & 0.02 & 0.10 & -0.03 & 0.02 & 0.20 & -0.02 & 0.02 & 0.26 \\
\hline \multicolumn{10}{|l|}{ Subcortical brain metrics } \\
\hline Amygdala, mean volume & 0.02 & 0.02 & 0.40 & 0.01 & 0.02 & 0.41 & 0.01 & 0.02 & 0.52 \\
\hline Hippocampus, mean volume & 0.01 & 0.02 & 0.42 & 0.01 & 0.02 & 0.42 & 0.01 & 0.02 & 0.50 \\
\hline \multicolumn{10}{|l|}{ Childhood adversities } \\
\hline \multicolumn{10}{|l|}{ Global brain metrics } \\
\hline Total brain volume & -0.11 & 0.02 & $<0.001$ & -0.08 & 0.02 & $<0.001$ & -0.07 & 0.02 & 0.001 \\
\hline Cortical grey matter volume & -0.11 & 0.02 & $<0.001$ & -0.08 & 0.02 & 0.001 & -0.07 & 0.02 & $0.003^{*}$ \\
\hline Cerebral white matter volume & -0.10 & 0.02 & $<0.001$ & -0.08 & 0.02 & 0.001 & -0.07 & 0.02 & $0.002 *$ \\
\hline Total cerebellar volume & -0.07 & 0.02 & 0.003 & -0.05 & 0.02 & 0.03 & -0.05 & 0.02 & 0.06 \\
\hline \multicolumn{10}{|l|}{ Subcortical brain metrics } \\
\hline Amygdala, mean volume & 0 & 0.02 & 0.90 & 0 & 0.02 & 0.87 & -0.01 & 0.02 & 0.70 \\
\hline Hippocampus, mean volume & -0.01 & 0.02 & 0.58 & -0.01 & 0.02 & 0.63 & -0.01 & 0.02 & 0.59 \\
\hline
\end{tabular}

Model 1 adjusted for child age at MRI scan, child sex, total intracranial volume (in subcortical metrics), maternal ethnicity. Model 2 additionally adjusted for the highest household education. Model 3 additionally adjusted for maternal prenatal alcohol use and smoking. All outcomes are standardized. $\mathrm{N}=2242$ in prenatal adversities analyses, $\mathrm{N}=2923$ in childhood adversities analyses. $*$ These p-values survived correction for multiple testing. 
Table 3. Interaction between prenatal adversities and adversities in childhood in relation to brain morphology

\begin{tabular}{|c|c|c|c|c|c|c|c|c|c|}
\hline & \multicolumn{3}{|c|}{$\begin{array}{l}\text { Main effect: } \\
\text { Prenatal } \\
\text { adversities }\end{array}$} & \multicolumn{3}{|c|}{$\begin{array}{l}\text { Main effect: } \\
\text { Adversities in } \\
\text { childhood }\end{array}$} & \multicolumn{3}{|c|}{ Interaction Effect } \\
\hline & B & SE & $\mathbf{P}$ & B & SE & $\mathbf{P}$ & B & SE & $\mathbf{P}$ \\
\hline \multicolumn{10}{|l|}{ Global metrics } \\
\hline Total brain volume & -0.02 & 0.02 & 0.33 & -0.10 & 0.03 & 0.002 & 0.04 & 0.03 & 0.15 \\
\hline Cortical grey matter volume & -0.02 & 0.02 & 0.33 & -0.10 & 0.03 & 0.001 & 0.04 & 0.03 & 0.08 \\
\hline Cerebral white matter volume & -0.02 & 0.03 & 0.55 & -0.09 & 0.03 & 0.01 & 0.02 & 0.03 & 0.40 \\
\hline Total cerebellar volume & -0.03 & 0.03 & 0.22 & -0.06 & 0.03 & 0.09 & 0.03 & 0.03 & 0.35 \\
\hline \multicolumn{10}{|l|}{ Subcortical metrics } \\
\hline Amygdala, mean volume & 0 & 0.02 & 0.96 & -0.02 & 0.03 & 0.43 & 0.03 & 0.02 & 0.24 \\
\hline Hippocampus, mean volume & 0.01 & 0.02 & 0.56 & 0.01 & 0.03 & 0.69 & 0 & 0.02 & 0.94 \\
\hline
\end{tabular}


Figure 1. Associations between prenatal and childhood adversities with the total brain volume.

\section{Adverse Events and the Total Brain Volume $(\mathrm{N}=2,172)$}

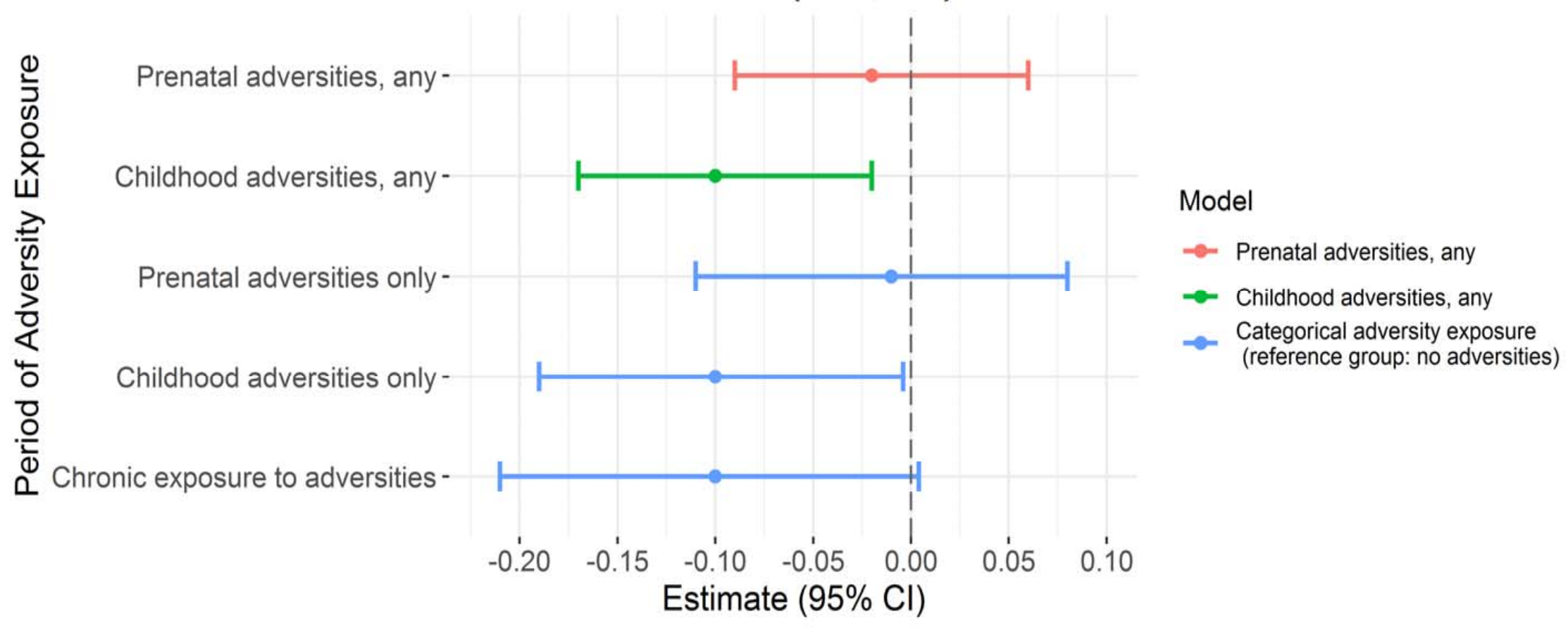

